\title{
Does Innovation Lead to Firm Growth? Explorative versus Exploitative Innovations
}

\author{
Pontus Braunerhjelm \\ KTH Royal Institute of Technology, SE-100 44 Stockholm, Sweden ${ }^{1}$ \\ pontus.braunerhjelm@indek.kth.se \\ Ding Ding \\ KTH Royal Institute of Technology, SE-100 44 Stockholm, Sweden \\ ding.ding@indek.kth.se
}

\begin{abstract}
In this paper, we examine the relationship between innovation and firm growth. We implement a classification of innovations based on whether they are explorative or exploitative, taking advantage of a unique Swedish dataset for the period 1997 to 2012. The data allow us to construct each firm's innovation history. Panel regression estimations, together with an instrumental variable method, confirm a significant and positive effect of both exploitative and explorative innovation on firms' employment growth. More radical explorative innovations are shown to have a more persistent growth effect, whereas exploitative innovation increases labour demand in the short run. We also provide empirical findings regarding the effect of innovations distributed on size classes and different ownership structures.
\end{abstract}

Keywords: Innovation, firm growth, exploration innovation, exploitation innovation

JEL Codes: O31, L25

\footnotetext{
${ }^{1}$ Pontus Braunerhjelm is also affiliated with the Swedish Entrepreneurship Forum. Financial support from the Marianne and Marcus Wallenberg's Foundation is gratefully acknowledged.
} 


\section{Introduction}

Understanding how innovation influences firm growth, and how different types of innovations affect productivity, employment and competitiveness, is high on the agenda for policy-makers. As firms convert knowledge into innovations and strengthen their market position, they are likely to contribute to economic growth and welfare. A large number of countries have also stressed innovation policies as a means to promote longterm growth and to build a knowledge economy based on a qualified and well-paid work force (Herstad, 2011). Globalization and rapid technological change has led to a stiffening in competition, which has further emphasized the importance of innovation.

Yet our knowledge regarding the relationship between innovation and employment remains surprisingly inapt. According to Harisson et al. (2014, p.2): "The consequences of innovation for employment are of particular interest, but the relationship between innovation and employment is not well-known". In the long-run perspective, innovation is clearly beneficial for growth and prosperity. However, in the short and medium terms, the aggregate effects of innovation on employment growth may go either way: One firm's success may imply another firm's decay due to business-stealing effects, or the innovative firm reduces parts of its previous production. Hence, it seems critically important to comprehend the effects at the micro level to design an appropriate long-term innovation policy. The link between innovation and employment can thus, and should, be studied at different levels of aggregation (Greenan and Guellec, 2000; Coad, 2009; Mastrostefano and Pianta, 2009). ${ }^{2}$

The focus we adopt in the current paper is to examine how different types of innovation influence employment growth at the firm level. Most previous studies categorize innovations into two main types: product and process innovations. ${ }^{3}$ The former

\footnotetext{
2 See Hall et al. (2008), Lachenmaier and Rottman (2011), Dachs and Peters (2014) and Harrison et al. (2014). For surveys, see also Pianta (2006), Coad (2009) and Vivarelli (2014). Dachs et al. (2015) provide evidence that product innovations generate employment in all stages of the business cycle. The theoretical literature is also ambiguous in its predictions of the effects of innovation on employment (Petit 1995).

${ }^{3}$ More recently, the role of organizational innovations has also been stressed, particularly in the service sector (Evangelista and Vezzani 2010).
} 
has been shown to generate predominantly positive (net) effects by reinforcing the demand for a firm's products and strengthening its market position. The latter is associated with more ambiguous effects, where the immediate result is the displacement of labour. However, over time, demand may increase for the firm's product, and the initial displacement effect may be replaced by compensatory effects that expand employment. The outcomes for both of these types of innovations depend on the elasticity of demand for the firm's product, whether innovations are labour- or capital-augmenting, the level of competition, entry and imitative behaviour, and the exits of competing firms. Often, there is no sharp distinction between the two types of innovation; either they overlap, or they take place in conjunction. ${ }^{4}$

We will implement a somewhat different classification of innovations. Rather than separating product and process innovations, we make a distinction depending on whether innovations are explorative or exploitative (March 1991; Akcigit and Kerr, 2013). The former innovation strategy can be characterized as having a search scope, indicating that firms undertake $R \& D$ to create new products that deviate from their previous knowledge profile. The latter refers to firms that focus on search depth, implying that improving current products and services, rather than changing firms' innovation strategies, is emphasized (Rowley et al., 2000; Hagedoorn and Duysters 2002; Katila and Ahuja, 2002). Both of these innovation types contain products and process innovation, but new or improved products dominate both strategies. ${ }^{5} \mathrm{We}$ believe that this measure more accurately captures firms' innovation activities than the dichotomous classification of product and process innovations.

\footnotetext{
${ }^{4}$ See Dougherty (1992), Mowery (2009) and Piening and Salge (2015). Firms' ability to exploit market and technological opportunities has also been claimed to be a function of, e.g., organizational capability, routines, knowledge bases, and their technical capacity related to R\&D departments, patent strategy and knowledge base (Herstad et al., 2015). This claim can be viewed as a Schumpeterian perspective. Resource-based theories (Penrose, 1959; Wernerfelt, 1984) have also been used to explain innovative activities. These theories conceptualize firm growth as intimately interlinked with the ability of firms to exploit the resources that are continuously created through their business processes and embedded in their workforces and organizational routines (Leonard-Barton, 1992; Wang et al., 2009).

${ }^{5}$ They could also be linked to Schumpeter Mark I creative destruction processes (explorative innovations) and Schumpeter Mark II cumulative knowledge accumulation patterns (exploitative) typical in oligopolistic markets (Malerba and Orsenigo 1995).
} 
Obviously, there are numerous pitfalls in the measurement of innovations. The most frequently used output measures of innovative activities are R\&D expenditures and patents. $R \& D$ expenditures suffer from the apparent drawback of applying an input measure to approximate innovative output. Patent is a better performance variable but is also burdened with obvious drawbacks related to time lags and the fact that not all inventions can be patented. ${ }^{6}$ More recent contributions have used data from innovation surveys, allowing for a broader group of firms to report on innovations (Evangelista and Vezzani, 2010). However, these also suffer from deficiencies, such as firms' own subjective evaluations of whether innovations have occurred, limited periods of time and restricted samples of firms.

Nonetheless, there is a clear tendency in the empirical literature to use R\&D investments and patent output to proxy innovation (Del Monte and Papagni, 2003; Coad and Rao, 2008; Demirel and Mazzucato, 2012). We will implement patent application as our measure of innovation, which is far from perfect but has the apparent advantage of being well defined, available for a large number of firms over long periods of time and related to firms' current innovative activities. In addition, an increasing number of firms in the service sectors also apply for patents. Using data on patent application, combined with patent classification, we create a knowledge profile for each firm at the two-digit level. Based on this knowledge profile, we can distinguish the different types of innovation. A patent application is labelled as an explorative innovation if the firm did not apply for a patent in the same patent class during the past five years; otherwise, it is considered an exploitative innovation.

Applying this measure on innovation, we contribute to the previous literature in several ways. First, we are able to distinguish between innovative strategies that are aimed at more disruptive and radical innovations and those more oriented towards incremental improvements. Second, we construct knowledge profiles for all firms included in the analysis, which enables us to detect switches in their innovation strategies, based on patent classes. Third, we have access to data going back two decades, which allows us to control for persistency in innovations. Fourth, we are able to identify both size and ownership

\footnotetext{
${ }^{6}$ See surveys by Chennells and Van Reenen (2002), Spieza and Vivarelli (2002) and Coad (2010).
} 
effects. Finally, we have a comprehensive dataset involving all firms in both the manufacturing and service industries.

Our estimations support the proposition that innovation has a positive effect on firm growth. More precisely, both explorative and exploitative innovations have a positive and significant effect on firms' employment growth. Comparing the two, we find that firms engaged in explorative innovations enjoy stronger employment growth. We apply several econometric techniques and conclude that the results are robust. In addition, the results support a persistent employment growth effect, though only in the case of explorative innovation. Finally, it should be stressed that innovation-induced growth effects are particularly important for small- and medium-sized firms and for young firms.

The rest of the paper is organized as follows. The next section reviews the previous research related to the issues addressed in this paper. Then, we present the empirical strategy in section three. The fourth section displays the description of the data, and the results are laid out in section five. Finally, the last section concludes.

\section{Previous research}

The forces of globalization and rapid technological progress emphasize the need for an innovative and competitive business sector. Moreover, because larger firms tend to expand in terms of employees primarily in foreign markets, the role for small firms with potentially strong growth prospects becomes even more important in governments' strife for full employment. Since the early 1990s, it has also been shown that new jobs primarily originate in smaller and new firms (Loveman and Sengenberger, 1991; Dachs et al., 2015). Presently, there is basically a consensus that SMEs are the main contributors of net job creation, even though the effect varies across economies (OECD 2013). ${ }^{7}$ Thus, Gibrat's law (Gibrat, 1931) has convincingly been rejected in numerous empirical studies, demonstrating that smaller firms seem to exhibit systematically higher growth rates than their larger counterparts. ${ }^{8}$

\footnotetext{
7 See Lotti et al. (2003) and Braunerhjelm (2008) for surveys.

${ }^{8}$ See Hall (1987), Geroski (1995), Sutton (1998), Caves (1998), Almus and Nerlinger (2000), Heshmati (2001) and Audretsch et al. (2006). Coad (2009) presents an excellent survey.
} 
Apart from creating employment, new and growing firms introduce products, processes, and business model innovations, develop new markets and change the rules of the game of their industries (Bhide, 2000). It is noteworthy that despite their modest R\&D investments, small and entrepreneurial firms have been shown to account for a substantial proportion of aggregate innovation (Audretsch, 1995; Feldman and Audretsch, 1999; Cefis, 2003; Jensen et al. 2007; Herstad and Brekke, 2012). Furthermore, new ventures are more prone to develop, use, and introduce radical, market-making products that give the firm a competitive edge over incumbents (Casson, 2002a; 2002b; Baumol, 2007). An impressive share of radical breakthrough innovations has been shown to originate from entrepreneurs and small firms. Almeida and Kogut (1997) and Almeida (1999) conclude that small firms innovate in relatively unexplored fields of technology, even though industry differences prevail regarding innovative activities' distribution between large and small firms. ${ }^{9}$

The implications of innovative activities in young and small firms are that they are likely to play a distinct and decisive role in the transformation and development of knowledge-based economies. Still, the issue of how innovation and firms' employment growth are related continues to be inconclusive. Previous empirical studies implement different types of data at different aggregation levels, and the overall results are ambiguous, although product innovation seems to have a weak positive impact on firm growth (Coad 2009).

\subsection{Relating innovation to firm growth}

The effects of innovation on growth have been analysed at different levels of aggregation and using different types of growth variables: revenues, value added or employment. Our focus is on labour growth at the firm-level. As more aggregated levels are considered, it becomes harder to disentangle growth stemming from innovation and growth due to industrial restructuring, entry, exits, and businesses cycle effects, to mention a few.

\footnotetext{
${ }^{9}$ See Rothwell and Zegveld (1982), Acs and Audretsch (1988, 1990), Baumol (2004), Audretsch (2005), Ortega-Argilés et al. (2009).
} 
In the literature, innovations are often categorized as product or process innovations, and more recently, organizational innovations have been added. As firms come up with new products, the short-run effects are to reduce competitive pressures and to strengthen their market position (Smolny, 1998). The consequences are to increase firms' production and employment. Over time, as the firm's previous products become obsolete, and depending on the degree of competition and the levels of entry and exit, production and employment volumes may level out or even decrease (Hall et al., 2008). Such displacement effects of innovation are, however, expected to be most prominent in the case of process innovations, particularly if the innovation implies that capital replaces labour. Nonetheless, process innovations may over time also lead to increases in production and employment if productivity is increased and prices are lowered (Harrison et al., 2014). The empirical results of how process innovation influences employment remain mixed (Niefert, 2005).

Hence, as noted by Herstad and Sandven (2015), innovation output may affect firm growth in basically two ways. First, the direct market response as a specific innovation is launched, which will influence the firm's incentive to adjust capacity to profit-maximizing levels. Second, indirect effects implying learning and the accumulation of knowledge, which may translate into other types of innovations that can either reinforce or dampen the direct market response.

Using detailed Swedish data, Andersson and Lööf (2009) show that innovation, as captured by patent applications, is highly skewed: One third of patent applications in the manufacturing sector emanates from firms with fewer than 25 employees. Compared to non-patenting firms, firms engaged in patenting have more skilled labour, larger profit margins and better access to bank loans, and often such firms belong to the high-technology segment of industries. Similar findings are reported by Deschryvere (2014), using data on Finnish firms, and Triguero et al. (2014), analysing Spanish firms.

Using R\&D as a proxy for innovation, Stam and Wennberg (2009) report that the growth effects of R\&D expenditure differ across firms. It is only the strong growth performers that benefit from increased $R \& D$ expenditures, and the effect is conditional upon other variables, such as having a previously established external network. Basically, $\mathrm{R} \& \mathrm{D}$ is shown to matter only for a limited group of new high-tech and high-growth firms. 
Other studies corroborate that R\&D has its most prominent effects on firms that belong to the high-tech sectors and that have already displayed strong growth (Coad and Rao, 2008; García-Manjón and Romero-Merino, 2008). Demirel and Mazzucato (2012), using a data set on U.S. pharmaceutical firms, report that R\&D spending positively influences smaller firms' growth but only for those that are persistent innovators. Larger firms may, by contrast, experience a negative effect of increased $R \& D$ layouts. Hence, they conclude that R\&D is not always worthwhile and that it would be misleading to think it will always generate firm-level growth.

Harrison et al. (2014), implementing survey data that comprise firms from both the manufacturing and service sectors, separate between those having no innovations, only process innovations and only product innovations. Controlling for a number of other variables, they conclude that productivity is higher among innovating firms and that the compensation effects dominate over displacement of labour; i.e., innovating firms grow. For the group, product innovators' demand is shown to fall for older products but that the decrease is outpaced by increasing demand for new products. By contrast, for firms involved in process innovation, a small negative effect is detected on employment. In the service sector, they find no evidence of displacement effects resulting from process innovation.

\subsection{Explorative and exploitative innovation}

March (1991) introduced the concepts of explorative and exploitative activities and argued that they are fundamental for organizations' learning processes. Whereas organizational exploration can be viewed as a search for new knowledge to create new products and processes, exploitation departs from a firm's existing knowledge, technologies and products. Hence, explorative and exploitative activities rely on different organizational characteristics and capabilities within firms and are intimately linked to firms' innovation strategies (Lewin et al., 1999; Benner and Tushman, 2003; Galunic and Eisenhardt, 2001; He and Wong, 2004).

Exploitation is a learning process assumed to primarily develop existing knowledge but not to widen the knowledge base (Rowley et al., 2000; Hagedoorn and Duysters, 2002). Firms that choose an exploitative innovation strategy are thus likely to increase efficiency 
but may reduce the ability to discover new products and processes and to adapt to changing circumstances. ${ }^{10}$ In contrast to exploitative innovation, explorative innovation strategies can generally be characterized as a break from existing knowledge routines. Explorative innovations that strive to develop new products and processes, which are of vital importance for survival and long-term performance, also stand a larger risk of incurring excessive costs that can endanger profitability and growth (Nooteboom, 2000; Hagedoorn and Duysters, 2002). Hence, firms have to make decisions under uncertainty regarding their innovation strategies, and they are also likely to change them over time (Corradini et al. 2016).

Akcigit and Kerr (2010) link the two types of innovations to growth. They conclude that smaller firms grow faster, that their R\&D-to-sales ratio exceeds that of larger firms, and that the relative rate of major, explorative innovations is higher in smaller firms. Small and entrepreneurial firms are thus claimed to have a comparative advantage in explorative innovations, whereas larger firms are more preoccupied with refining existing products. Hence, small firms come up with a disproportionate share of major innovations. Still, Akcigit and Kerr do not stress how employment growth is distributed between firms adopting the two different innovation strategies; rather, their focus is growth at the aggregate level.

To summarize, previous research suggests that small firms exhibit the highest employment growth and are most likely to come up with radical innovations, that R\&D is not always a good indicator of innovations, and that the effects of employment growth are strongest for product innovations. Similarly, explorative and exploitative innovations may be a better way to capture firms' innovations strategies. Based on the literature survey and the innovation strategy choices that firms face, we expect firms' employment growth to be i) positively related to both explorative and exploitative innovative activities, ii) particularly so for firms involved in explorative innovation strategies and iii) for firms adopting persistent innovation strategies.

\footnotetext{
${ }^{10}$ It has, for instance, been argued that firms focusing on exploitative innovation strategies have a drawback in adapting to novel environmental requirements (Michl et al, 2013).
} 


\section{Econometric strategy}

We embark from a standard log linear employment equation proposed by Layard and Nickell (1986), modified to first differences to eliminate the firm fixed effect:

$$
\Delta n_{i t}=\alpha_{1} \Delta n_{i(t-1)}+\alpha_{2} \Delta n_{i(t-2)}+\beta_{1} \Delta w_{i t}+\beta_{2} \Delta k_{i t}+\beta_{3} \Delta y s_{i t}+\Delta \varepsilon_{i t}
$$

where $\Delta n_{i t}=n_{i t}-n_{i(t-1)}$ is the first difference of the logarithm of the employment of firm $i$ at year $t$. All other continuous variables are defined in the same way. We control for nominal wage rate $w_{i t}$, gross fixed capital $k_{i t}$ and industry output $y s_{i t}$ which captures expected real demand (Nickell 1986). Higher demand can be expected to result in more employment. Finally, $\varepsilon_{i t}$ is the error term, expected to exhibit standard properties.

In equation 2, we use both current and lagged innovation activities, categorized as explorative or exploitative innovations:

$$
\begin{aligned}
& \Delta n_{i t}=\alpha_{1} \Delta n_{i(t-1)}+\alpha_{2} \Delta n_{i(t-2)}+\beta_{1} \Delta w_{i t}+\beta_{2} \Delta k_{i t}+\beta_{3} \Delta y s_{i t}+\beta_{4} \text { Exploitative }_{i t}+ \\
& \beta_{5} \text { Explorative }_{i t}+\beta_{6} \text { Exploitative }_{i(t-1)}+\beta_{7} \text { Explorative }_{i(t-1)}+\beta_{8} \text { Exploitative }_{i(t-2)} \\
& +\beta_{9} \text { Explorative }_{i(t-2)}+\mathbf{X}_{\mathbf{i t}}^{\prime} \boldsymbol{\delta}+\Delta \varepsilon_{i t}
\end{aligned}
$$

where vector $\mathrm{X}$ contains the following control variables: $D_{\text {Ownership }}$, which refers to ownership structure, $D_{\text {industry }}$, which is associated with 21 sub-industries ${ }^{11}$, and $D_{\text {time }}$, which controls for the time trend (annual dummies) during 2002 to 2012. Finally, $D_{\text {region }}$ takes into account the regional effects. ${ }^{12}$

\footnotetext{
${ }^{11}$ See Coad (2009). The industry classifications are based on standard Swedish industrial classification "SIC2007", which is identical to the first four levels of NACE Rev. 2. In this paper, we use the first level of SIC2007 to identify 21 industries.

${ }^{12}$ We introduce functional regions (FA regions) as our spatial unit of measurement according to the Swedish Agency for Economic and Regional Growth (Tillväxtverket). There are 72 FA regions in Sweden based on the commuter distance to the respective region's capital.
} 
Both OLS and system-GMM techniques are used to estimate equation (2). The latter one, developed by Blundell and Bond (1998), implies that lagged variables are used as instruments to control for potential endogeneity. First, and most obviously, lagged dependent variable $\Delta n_{i(t-1)}$ is potentially correlated with error term $\Delta \varepsilon_{i t}$ and therefore risks introduce endogeneity in the estimations. Following Lachenmaier and Rottmann (2011), we use $n_{i(t-3)}$ and earlier realizations of $n_{i t}$ as instruments for first difference lagged dependent variable $\Delta n_{i(t-1)}$.

Second, one might consider the endogeneity of our two innovation variables. As suggested by Lachenmaier and Rottmann (2011), innovation decisions are often based on long-term considerations, while employment decisions are based on more short-term considerations. If we assume that innovation decisions are made at least one period before employment decisions, then we can consider innovation decisions as predetermined. Predetermined variables can be correlated with previous error terms, whereas endogenous variables can be correlated with both previous and current error terms. We instrument our innovations variables with their one-period lagged level values, which we assume are uncorrelated with the error term. The validity of this assumption is tested by the Sargan test (Blundell and Bond, 1998).

\section{Data and descriptive statistics}

The data have been acquired from the Statistics Sweden's Business Register, and they cover all registered firms and establishments in Sweden since 1987. Data on patent classifications go back to 1997. The first five years are, however, needed to distinguish between explorative and exploitative innovations and can therefore not be included in the estimation period. Hence, our estimations are based on data from the period 2002 to 2012.

Patent application data have been obtained from the European Patent Office's PATSTAT database supplemented with data from the Swedish Patent Office, which includes International Patent Classifications (IPC) since 1997. Firms' serial ID number has enabled a matching between firms and patent applications. Pooling firm-level data and 
patent application data leaves us with a sample of 2,159,666 observations from 482,513 firms across 20 industries.

For all firms, a patent history profile is created based on the patents the firm applied for during a five-year moving window ${ }^{13}$ prior to any given year. ${ }^{14}$ The firm's patent history profile enables us to distinguish between patent applications categorized as either explorative or exploitative. A patent is labelled explorative if a firm applies for a patent in a patent class that is new for the firm. If the firm applies for a patent in the same class as it has previously applied during a five-year moving window, the firm is defined as exploitative. Hence, we construct the following two innovation variables:

Exploitative innovation: A dummy variable equal to one if a firm applies for a patent in year $t$ in a patent class where it already has applied for a patent during the past five years; zero otherwise.

Explorative innovation: A dummy variable equal to one if a firm applies for a patent in year $t$ within a patent class where it has not applied for a patent during the past five years; zero otherwise.

The wage variable $\left(w_{i t}\right)$, measured as wage costs per employee, the gross fixed capital stock $\left(k_{i t}\right)$ and industrial output $\left(y s_{i t}\right)$, are all deflated using the producer price index. The gross output of industry is obtained by aggregating the gross value added, and it supposedly represents the expected aggregate demand. Finally, we distinguish between four different types of firm ownership in the analysis: domestically owned independent firms (DIFs), domestically owned firms belonging to a Swedish corporate group (DSC), domestically owned multinational firms (DMNEs) and foreign-owned multinational firms

\footnotetext{
${ }^{13}$ We follow Griliches $(1979,2007)$ findings that knowledge capital loses most of its economic value during the first five years and use a five-year window to distinguish between explorative and exploitative innovations. As a robustness test, we also employ a shorter window comprising three years.

${ }^{14}$ The patent applications classed are determined at the two-digit level of International Patent Classification (IPC), which results in 121 classes. A similar method was used by Bloom et al., (2013), who used firm-level data on patenting in different technology classes to locate firms in technology space.
} 
$(\text { FMNEs })^{15}$. Table 1 provides the definitions of all variables employed in the analysis, Table 2 reports descriptive statistics, and Table 3 presents the pairwise correlation coefficients.

\section{TABLE 1 HERE}

TABLE 2 HERE

TABLE 3 HERE

We find that the two innovation variables are positively correlated (the correlation coefficient is equal to 0.46 ) regardless of whether we use a three- or a five-year window, suggesting that firms involved in one type of innovation are likely to also pursue the other type of innovation. In addition, it is obvious that the main part of our sample consists of domestically owned independent firms (DIFs), followed by domestically owned firms belonging to a Swedish corporate group (DSCs). Together, these two types of firms comprise over 94 percent of all firms. The vast majority of firms (almost 60 percent) belong to the manufacturing, construction, wholesale, retail and professional and technical industries. Table 4 shows descriptive statistics distributed on the four ownership categories.

\section{TABLE 4 HERE}

DIFs constitute the largest part, representing 80.6 percent of all firms. The average annual employment growth among DIFs was 3.1 percent, followed by DMNEs ( 0.8 percent), DSCs (0.8 percent) and FMNEs (0.4 percent). DIFs are small firms with an average of four employees; they are endowed with modest amounts of physical capital and are poor innovators. On average, 0.036 percent of firms belonging to this owner category

\footnotetext{
${ }^{15}$ Ownership has been shown to influence firms' employment growth and innovative activities, but results are inconclusive (Barba Navaretti, 2004; Geroski and Gugler, 2004; Beck et al., 2005; Ebersberger et al., 2005; Sadowski and Sadowski-Rasters, 2006; Dachs et al., 2008; Dachs and Peters, 2014).
} 
had an explorative innovation, and 0.038 percent had an exploitative innovation during 2002 to 2012.

Categories DMNEs and FMNEs contain the largest firms (approximately 95 employees on average), which also have considerably more physical capital and are more innovative. DMNEs perform better in terms of innovation output than FMNEs. In DMNEs, 1.6 percent of firms are involved in explorative innovation, and 2.7 percent are involved in exploitative innovation; in FMNEs, 1.0 percent of firms are involved in explorative innovation, and 1.8 percent are involved in exploitative innovation.

Looking at Figure 1, we can observe the fluctuation of the average growth rate during 2002 to 2012. Both explorative innovators and exploitative innovators enjoy a higher average growth rate of employment than non-innovators, but the growth rate has a tendency to change frequently. After the "great recession" starting in 2008, the decline in growth rate has been most pronounced for innovative firms. For non-innovators, the decrease is more smooth, from 4.1 percent in 2007 to 0.4 percent in 2009.

\section{FIGURE 1 HERE}

Comparing innovators, explorative strategies seem to be consistent with a considerably higher growth rate throughout the entire period than firms adopting exploitative strategies. Both explorative and exploitative innovators experienced the highest growth up until 2007 (10.5 percent for explorative innovators and 6.6 percent for exploitative innovators). However, they also suffered the sharpest decline after 2008. This finding illustrates that even if innovation creates competitiveness, it may also expose firms to considerable risks. 


\section{Empirical results}

The results from the regressions implementing OLS are presented in Table 5, and the system-GMM estimation results are shown in Table 6. Specifications 1 and 2 include the explorative and exploitative innovation variables separately, whereas specification 3 includes both types of innovations simultaneously.

\section{TABLE 5 HERE}

\section{TABLE 6 HERE}

The first apparent thing in Table 5 is the strong and highly significant negative relationship between current growth and the lagged employment growth variables, which could be interpreted as an indication of mean reversion; i.e., firms that have experienced high employment growth one year tend to see slower growth rates the following years, and vice versa. Notably, this effect disappears when we use the more elaborate GMM estimator, as shown by the overall lack of statistical significance for the lagged employment growth variables in Table 6.

Next, looking at the innovation variables in specifications 1 and 2, we find that both exploitative and explorative innovations are associated with positive and significant effects on subsequent firm growth. This result is qualitatively equal for both the OLS and the GMM estimates, but the strength differs somewhat between the two methods. In general, the effects tend to be slightly larger when looking at the GMM results than those obtained via OLS. This finding could potentially be due to the presence of endogeneity, making the OLS estimator both biased and inconsistent.

The strength of the positive relationship between innovation and employment growth decreases over time for both types of innovations. It even turns negative for exploitative innovations after two years, as indicated by the statistically significant negative sign for the two-year lagged dummy variable for exploitative innovations. A possible interpretation of this finding is that firms that have chosen an exploitative 
innovation strategy may enjoy efficiency gains in the short term, whereas it may take some time before it results in a reduced workforce. ${ }^{16}$ Over time, an exploitative innovation strategy may also hamper firms' ability to discover new products, which would further decrease the demand for new labour. Explorative innovations based on a wider search activity are more likely to come up with new products and processes and to generate an increase in labour demand. Note that both explorative and exploitative innovations are included in the regressions simultaneously, though only the former remains statistically significant, likely due to the high pairwise correlation between the two innovation variables shown in Table 3.

Our control variables, i.e., the wage rate, the capital stock and the sector gross value added, all have their expected signs and are highly significant. Higher wage growth is associated with lower employment growth, whereas an increasing capital stock goes handin-hand with stronger employment growth. Thus, it seems as if excessive labour costs make firms shed labour, while capital deepening is positively associated with higher marginal productivity of labour and contributes to employment growth. Moreover, as expected, there is a positive relationship between overall sector expansion and demand for labour, as evidenced by the positive sign of the aggregate sector value-added variable.

Finally, turning to the ownership variables, we see that the only category consistently differing from domestically owned individual firms in Tables 5 and 6 is FMNEs. That result is unexpected considering that FMNEs are believed to have a higher potential (e.g., sale organizations, access to global markets) to introduce new products more successfully into the market, which should be mirrored by higher employment growth. However, our results show that firms belonging to this category on average display a lower employment growth rate. One explanation could be that FMNEs adopt less labourintensive production technologies in high-wage countries such as Sweden. Potentially positive employment effects from innovation may predominantly be substantiated in foreign-owned plants outside of Sweden.

\footnotetext{
${ }^{16} \mathrm{~A}$ number of countries, including Sweden, have different safeguards for employees that imply that they cannot be dismissed from one day to the other.
} 
Second, the effect of innovation on employment creation is much larger in upswings of the business cycle than in downswings (Peters, 2008; Lucchese and Pianta, 2012). We have also shown that the employment growth rate dropped most for innovative firms after the financial crisis (Figure 1). The period we have chosen for the analysis covers two economic recessions (2002-2004 and 2007-2010) but only one upswing. From a dynamic perspective, the slow-down in the employment growth of foreign-owned firms might be explained by the business cycle.

In an attempt to test the robustness of our results, we use a three-year window to categorize innovations as explorative or exploitative as a complement to our baseline fiveyear window. As seen in Appendices A and B, basically all our results remain unchanged when we use this alternative measure, and we conclude that we have a stable and significant relationship between innovations and employment growth at the firm level.

The test statistics shown in the bottom rows in Table 6 and Appendix B support the validity of the system-GMM method. The Sargan test does not reject the null hypothesis that our instruments are exogenous, and furthermore, the AR (2) test does not reject the null hypothesis of no second order autocorrelation at the 5 percent significance level.

\section{Conclusion}

The purpose of this paper is to empirically examine how innovation influences firm growth measured in terms of employment. Building on previous theoretical and empirical findings, we create knowledge profiles to distinguish between exploitative and explorative innovations to investigate how different types of innovation have influenced firm growth.

We apply a dynamic analysis and use first difference employment equation techniques in the regressions, where Swedish firm level data for the period 2002 to 2012 are implemented. The results confirm significant and positive effects for both exploitative and explorative innovation on firm's employment growth. The results are shown to be robust to different estimation techniques, such as OLS regression and the GMM system method, and different measurements for innovation variables. 
We find that explorative innovation has a more pronounced and persistent effect on employment growth. This type of innovation adheres more closely to Schumpeter's early view on the role of the entrepreneur in initiating creative destruction processes. Exploitative innovations increase labour demand only in the short run, according to our estimations.

In addition, we also investigate the relationship between employment growth and ownership structure, which is essential for understanding the employment effect of foreignand domestically owned firms. Among four owner types, foreign-owned multinational enterprises (FMNEs) are shown to exhibit the lowest employment growth. This finding may reflect a higher capability of transforming innovations into higher productivity, or it may show that innovations are primarily used in affiliates outside of Sweden and thereby do not influence local demand for labour. Multinational enterprises may also have a tendency to use less labour-intensive production in a high wage country such as Sweden and move labour-intensive production into low-wage countries. In addition, we control for a number of other variables that are likely to affect firm growth, such as physical capital, wages, regions, industries and time trends.

The different effect of exploitative and explorative innovations for firm growth has important implications for government policies, aiming at full employment and economic growth. Business-stealing effects may imply that the aggregate effects will be smaller or even negligent. The results of our study may also be affected by the time period we are studying, even though we implement time dummies. As shown by Dachs et al. (2015), the effects of innovation on growth are larger in economic booms than in busts, and our data cover one upturn and two downturns.

From a policy perspective, it is important to comprehend how different policy measures influence innovation. As shown in numerous previous studies, $R \& D$ may not be an optimal policy instrument for all firms. For instance, Acemoglu et al. (2013) claim that $R \& D$ subsidies to incumbents reduce welfare and deter the entry of high-tech firms. If it is the case that smaller and young firms are more inclined towards explorative innovations, as our analysis indicates, then policies should implement instruments other than R\&D 
subsidies. The relationship between the type of innovation and size seems to be an important area for future research to more thoroughly investigate. 


\section{References}

Acs, Z. and Audretsch, D., (1988), Innovation in large and small firms: An empirical analysis. American Economic Review, 78(4), 678-690.

Acs, Z. and Audretsch, D., (1990), Innovation and Small Firms. Cambridge: MIT Press.

Akcigit, U and Kerr, W., (2013),"Growth through heterogenous innovations", Bank of Finland Research DP, No. 28, Helsinki.

Alcacer, J. and M. Gittelman (2006). Patent citations as a measure of knowledge flows: The influence of examiner citations. The Review of Economics and Statistics, 88(4): 774-779.

Almeida, P. (1997). The exploration of technological diversity and the geographic. Small Business Economics, 9(1), 21-31.

Almeida, P., and Kogut, B. (1999). Localization of knowledge and the mobility of engineers in regional networks. Management Science, 45(7), 905-917.

Almus, M. (2000). Testing "Gibrat's Law" for young firms-empirical results for eest Germany. Small Business Economics, 15(1), 1-12.

Audretsch, D., (1995), Innovation and Industry Evolution. Cambridge: MIT Press.

Audretsch, D., Keilbach, M. and Lehmann, E., (2006), Entrepreneurship and Economic Growth. New York: Oxford University Press.

Barba Navaretti, G. (2004). Host country effects: conceptual framework and the evidence in: Barba Navaretti, G., Venables, A.J. (Eds.), Multinational Firms in the World Economy. Princeton University Press, Princeton and Oxford, pp. 151-182.

Baumol, W., (2004), Entrepreneurial enterprises, large established firms and other components of the free-market growth machine. Small Business Economics, 23(1), 9-21.

Baumol, W. (2005). Small firms: Why market-driven innovation can't get along without them. The Small Business Eeconomy: A report to the President, 183-206.

Beck, T., Demirgüç-Kunt, A. S. L. I., and Maksimovic, V. (2005). Financial and legal constraints to growth: does firm size matter?. The Journal of Finance, 60(1), 137-177.

Becker, W. and J. Peters (2000). Technological opportunities, absorptive capacities, and innovation, Volkswirtschaftliche Diskussionsreihe, Institut für Volkswirtschaftslehre der Universität Augsburg.

Benner, M. J., and Tushman, M. L. (2003). Exploitation, exploration, and process management: The productivity dilemma revisited. Academy of Management Review, 28(2), 238-256.

Bhide, A., (2000), Theorigin and evolution of new businesses. New York: Oxford University Press.

Bloom, N., Schankerman, M., and Van Reenen, J. (2013). Identifying Technology Spillovers and Product Market Rivalry. Econometrica, 81(4), 1347-1393.

Braunerhjelm, P. (2008). Entrepreneurship, knowledge and economic growth. Now Publishers Inc.

Casson, M., (2002a), Entrepreneurship, business culture and the theory of the firm. In Acs, Z. and Audretsch, D. (eds.), The International Handbook of Entrepreneurship Research, Berlin and New York: Springer Verlagh.

Casson, M., (2002b), The Entrepreneur: An economic theory. Northampton, MA: Edward Elgar. 
Caves, R. E. (1998). Industrial organization and new findings on the turnover and mobility of firms. Journal of Economic Literature, 36(4), 1947-1982.

Cefis, E., and Orsenigo, L. (2001). The persistence of innovative activities: A cross-countries and cross-sectors comparative analysis. Research Policy, 30(7), 1139-1158.

Cefis, E. (2003). Is there persistence in innovative activities?. International Journal of Industrial Organization, 21(4), 489-515.

Chennells, L., and Van Reenen, J. (2002). Technical change and the structure of employment and wages: A survey of the microeconometric evidence. Productivity, Inequality and the Digital Economy, MIT Press, Cambridge, MA, 175-223.

Coad, A., and Rao, R. (2008). Innovation and firm growth in high-tech sectors: A quantile regression approach. Research Policy, 37(4), 633-648.

Coad, A. (2009). The growth of firms: A survey of theories and empirical evidence: Edward Elgar Publishing.

Coad, A. (2010). Investigating the exponential age distribution of firms. Economics: The OpenAccess, Open-Assessment E-Journal, 4.

Cohen, W. M., and Levinthal, D. A. (1990). Absorptive capacity: a new perspective on learning and innovation. Administrative science quarterly, 128-152.

Corradini, C., Demirel, P. and Battisti, G (2016), Technological diversification within UK's small serial innovators. Small Business Economics, online version.

Crépon, B., E. Duguet and J. Mairessec (1998). Research, innovation and productivity: An econometric analysis at the firm level. Economics of Innovation and New Technology, 7(2): 115158.

Dachs, B., and Peters, B. (2014). Innovation, employment growth, and foreign ownership of firms: A European perspective. Research Policy, 43(1), 214-232.

Dachs, B., Ebersberger, B., and Lööf, H. (2008). The innovative performance of foreign-owned enterprises in small open economies. The Journal of Technology Transfer, 33(4), 393-406.

Dachs, B., Hud, M., Koelher, C. and Peters, B. (2015), Employment effects of innnovation over the business cycle: Firm level evidence from European countries, mimeo, AIT, Vienna.

Davidsson, P., Lindmark, L., and Olofsson, C. (1994). New firm formation and regional development in Sweden. Regional Studies, 28(4), 395-410.

Davidsson, P., Delmar, F., and Wiklund, J. (2006). Entrepreneurship as growth; growth as entrepreneurship. Entrepreneurship and the Growth of Firms, 21-38.

Del Monte, A., and Papagni, E. (2003). R\&D and the growth of firms: Empirical analysis of a panel of Italian firms. Research Policy, 32(6), 1003-1014.

Demirel, P., and Mazzucato, M. (2012). Innovation and firm growth: Is R\&D worth it?. Industry and Innovation, 19(1), 45-62.

Deschryvere, M. (2014). R\&D, firm growth and the role of innovation persistence: an analysis of Finnish SMEs and large firms. Small Business Economics, 43(4), 767-785.

Dosi, G. (1997). Opportunities, incentives and the collective patterns of technological change. Economic Journal, 107(444): 1530-1547.

Dougherty, D. (1992). A practice-centered model of organizational renewal through product innovation. Strategic Management Journal, 13(S1), 77-92. 
Ebersberger, B., Lööf, H., and Oksanen, J. (2005). Does foreign ownership matter for the innovation activities of Finnish firms. Working Paper 26. Espoo: VTT.

Evangelista, R., and Vezzani, A. (2010). The economic impact of technological and organizational innovations. A firm-level analysis. Research Policy, 39(10), 1253-1263.

Feldman, M. and Audretsch, D., (1999), Innovation in cities: Science-based diversity, specialization and localized competition. European Economic Review, 43(2), 409-429.

Fernandes, A. M., and Paunov, C. (2014). The risks of innovation: Are innovating firms less likely to die?. Review of Economics and Statistics, (00).

Galunic, D. C., and Eisenhardt, K. M. (2001). Architectural innovation and modular corporate forms. Academy of Management Journal, 44(6), 1229-1249.

Geroski, P. A. (1995). What do we know about entry?. International Journal of Industrial Organization, 13(4), 421-440.

Geroski, P. A. (2005). Understanding the implications of empirical work on corporate growth rates, managerial and Decisions Economics, 26, 129-138.

Geroski, P.A. and Gugler, K. (2004). Corporate growth convergence in Europe, Oxford Economic papers, 56, 597-620.

Gibrat, R. (1931). Les inégalités économiques. Recueil Sirey.

Greenan, N., and Guellec, D. (2000). Technological innovation and employment reallocation. Labour, 14(4), 547-590.

Griliches, Z. (1979). Issues in assessing the contribution of research and development to productivity growth. The Bell Journal of Economics, 92-116.

Griliches, Z. (1990). Patent statistics as economic indicators: A survey. Journal of Economie Literature, 28(4), 1661-1707.

Griliches, Z. (Ed.). (2007). $R \& D$, patents and productivity. University of Chicago Press.

Hagedoorn, J., and Duysters, G. (2002). Learning in dynamic inter-firm networks: the efficacy of multiple contacts. Organization studies, 23(4), 525-548.

Hall, B. H. (1987). Unpublished appendices from the relationship between firm size and firm growth in the US manufacturing sector. Journal of Industrial Economics, 35, 583-606.

Hall, B., Lotti, F. and Mairesse, J. (2008), Employment , innovation and productivity: evidence from Italian micro-data, Industrial and Corporate Change, 17, 813-869.

Harrison, R., Jaumandreu, J., Mairesse, J., and Peters, B. (2014). Does innovation stimulate employment? A firm-level analysis using comparable micro-data from four European countries, International Journal of Industrial Organization, 35, 29-43.

Herstad, S. (2011). Paradigms, regimes and the shifting notions of institutional best practice. Journal of the Knowledge Economy, 2(2), 173-191.

Herstad, S., and Brekke, T. (2012). Globalization, modes of innovation and regional knowledge diffusion infrastructures. European Planning Studies,20(10), 1603-1625.

Herstad, S. J., and Sandven, T. (2015). When are recruited competences supportive of innovation? Inter-industry differences in the importance of similarity and diversity (No. 1505). Utrecht University, Section of Economic Geography. 
Herstad, S. J., Sandven, T., and Ebersberger, B. (2015). Recruitment, knowledge integration and modes of innovation. Research Policy, 44(1), 138-153.

Heshmati, A. (2001). On the growth of micro and small firms: evidence from Sweden. Small Business Economics, 17(3), 213-228.

He, Z. L., and Wong, P. K. (2004). Exploration vs. exploitation: An empirical test of the ambidexterity hypothesis. Organization science, 15(4), 481-494.

Janz, N., H. Lööf and B. Peters (2004). Firm level innovation and productivity-ss there a common story across countries?, Royal Institute of Technology, CESIS-Centre of Excellence for Science and Innovation Studies.

Jensen, M. B., Johnson, B., Lorenz, E., and Lundvall, B. Å. (2007). Forms of knowledge and modes of innovation. Research Policy, 36(5), 680-693.

Katila, R., and Ahuja, G. (2002). Something old, something new: A longitudinal study of search behavior and new product introduction. Academy of Management Journal, 45(6), 1183-1194.

Koenig, H., F. Laisney, M. Lechner and W. Pohlmeier (1993). On the dynamics of process innovative activity: An empirical investigation using panel data, ZEW Discussion Papers.

Layard, R., and Nickell, S. (1986). Unemployment in britain. Economica, S121-S169.

Lotti, F., Santarelli, E. and Vivarelli, M. (2003), Does Gibrat's law hold among young , small firms?, Journal of Evolutionary Economics, 13, 213-235.

Leonard-Barton, D. (1992). Core capabilities and core rigidities: A paradox in managing new product development. Strategic Management Journal, 13(S1), 111-125.

Lewin, A. Y., Long, C. P., and Carroll, T. N. (1999). The coevolution of new organizational forms. Organization Science, 10(5), 535-550.

Loveman, G., and Sengenberger, W. (1991). The re-emergence of small-scale production: An international comparison. Small Business Economics, 3(1), 1-37.

Love, J. H. and S. Roper. (2001). Location and network effects on innovation success: Evidence for UK, German and Irish manufacturing plants. Research Policy, 30(4): 643-661.

Lucchese, M., Pianta, M. (2012). Innovation and employment in economic cycles. Comparative Economic Studies 54, 341-359.

Lööf, H. and A. Heshmati (2002). Knowledge capital and performance heterogeneity: A firm-level innovation study. International Journal of Production Economics, 76(1): 61-85.

Mastrostefano, V., and Pianta, M. (2009). Technology and jobs. Economics of Innovation and New Technology, 18(8), 729-741.

Malerba, F., and Orsenigo, L. (1995). Schumpeterian patterns of innovation. Cambridge Journal of Economics, 19(1), 47-65.

March, J. G. (1991). Exploration and exploitation in organizational learning. Organization Science, 2(1), 71-87

Michl, T., Gold, B., and Picot, A. (2013). Managing strategic ambidexterity: The spin-along approach. International Journal of Technology Management, 61(1), 47-63.

Mowery, D. C. (2009). Plus ca change: Industrial R\&D in the "third industrial revolution". Industrial and Corporate Change, 18(1), 1-50. 
Niefert, M. (2005). Patenting behaviour and employment growth in German start-up firms: A panel data analysis, Discusion paper No. 05-03, ZEW Center for European Economic Research, Mannheim.

Nightingale, P., and Coad, A. (2014). Muppets and gazelles: political and methodological biases in entrepreneurship research. Industrial and Corporate Change, 23(1), 113-143.

Nooteboom, B. (2000). Learning and innovation in organizations and economies: OUP Oxford.

Nooteboom, B., Van Haverbeke, W., Duysters, G., Gilsing, V., and Van den Oord, A. (2007). Optimal cognitive distance and absorptive capacity. Research policy, 36(7), 1016-1034.

Ortega-Argilés, R., Vivarelli, M., and Voigt, P. (2009). R\&D in SMEs: a paradox?. Small Business Economics, 33(1), 3-11.

Penrose, E. T. (1995). The theory of the growth of the firm. Oxford University Press.

Pesola, H. (2011). Labour mobility and returns to experience in foreign firms. The Scandinavian Journal of Economics, 113(3), 637-664.

Peters, B. (2008). Innovation and firm performance: An empirical investigation for German firms (Vol. 38). Springer Science and Business Media.

Pianta, M. (2006), Innovation and employment, in Fagerberg, J., Mowery, D. and Nelson, R. (eds.), Handbook of Innovation, Oxford University Press: Oxford.

Piening, E. P., and Salge, T. O. (2015). Understanding the Antecedents, Contingencies, and Performance Implications of Process Innovation: A Dynamic Capabilities Perspective. Journal of Product Innovation Management, 32(1), 80-97.

Robson, P. and Bennet, R. (2000). SME growth: The relationship with business advice and external collaboration, Small Business Economics, 15, 193-208.

Rothwell, R. and Zegveld, W., (1982), Innovation and the small and medium sized firm. London: Pinter Publishers.

Rowley, T., Behrens, D., and Krackhardt, D. (2000). Redundant governance structures: An analysis of structural and relational embeddedness in the steel and semiconductor industries. Strategic Management Journal, 21(3), 369-386.

Sadowski, B. M., and Sadowski-Rasters, G. (2006). On the innovativeness of foreign affiliates: Evidence from companies in The Netherlands. Research Policy, 35(3), 447-462.

Spiezia, V., and Vivarelli, M. (2002). Innovation and employment: A critical survey. Greenan, N.L'Horty Y.-Mairesse, J.(eds.), Productivity, Inequality and the Digital Economy: A Transatlantic Perspective, MIT Press, Cambridge (Mass.), 101-31.

Stam, E., and Wennberg, K. (2009). The roles of R\&D in new firm growth. Small Business Economics, 33(1), 77-89.

Stuart, T. E., and Podolny, J. M. (1996). Local search and the evolution of technological capabilities. Strategic Management Journal, 17(S1), 21-38.

Triguero, A., Córcoles, D., and Cuerva, M. C. (2014). Persistence of innovation and firm's growth: Evidence from a panel of SME and large Spanish manufacturing firms. Small Business Economics, 43(4), 787-804.

Vivarelli, M. (2014). Innovation, employment and skills in advanced and developing countries: A survey of economic literature, Journal of Economic Issues, 48, 123-154. 
Wang, H. C., He, J., and Mahoney, J. T. (2009). Firm-specific knowledge resources and competitive advantage: The roles of economic-and relationship-based employee governance mechanisms. Strategic Management Journal, 30(12), 1265-1285.

Wernerfelt, B. (1984). A resource-based view of the firm. Strategic Management Journal, 5(2), 171-180. 
Table 1 Definition of variables

\begin{tabular}{|c|c|c|c|}
\hline Symbol & Variables & Type & Definition \\
\hline$n_{i t}$ & Log employment & $\mathrm{C}$ & $\begin{array}{l}n_{i t} \text { is the logarithm of the employment of } \\
\text { firm } i \text { at year } t \text {. }\end{array}$ \\
\hline$\Delta n_{i t}$ & Employment growth & $\mathrm{C}$ & $\Delta n_{i t}=n_{i t}-n_{i(t-1)} ;$ the value had been \\
\hline Explorative $_{i t}$ & Explorative innovation & $0 / 1$ & $\begin{array}{l}\text { winsorized at a } 1 \% \text { level for each tail. } \\
\text { A dummy variable equal to one if a firm } \\
\text { applied patents in year } t \text { within the patent } \\
\text { application classes in which it had not been } \\
\text { active in the past } 5 \text { years; zero otherwise. }\end{array}$ \\
\hline Exploitative $_{i t}$ & Exploitative innovation & $0 / 1$ & $\begin{array}{l}\text { A dummy variable equal to one if a firm } \\
\text { applied patents in year } t \text { within the patent } \\
\text { application classes in which the firm had } \\
\text { been active in the past } 5 \text { years; zero } \\
\text { otherwise. }\end{array}$ \\
\hline$w_{i t}$ & Log deflated wage & c & $\begin{array}{l}\text { The logarithm of the firm's average wage } \\
\text { deflated by the producer price index (PPI). }\end{array}$ \\
\hline$k_{i t}$ & Log physical capital & $\mathrm{c}$ & $\begin{array}{l}\text { The logarithm of the value of physical } \\
\text { capital deflated by the producer price index } \\
\text { (PPI). }\end{array}$ \\
\hline$y s_{i t}$ & $\begin{array}{l}\text { Log sector gross value } \\
\text { added }\end{array}$ & $\mathrm{c}$ & $\begin{array}{l}\text { The logarithm of the aggregate sector gross } \\
\text { value added deflated by producer price } \\
\text { index (PPI). }\end{array}$ \\
\hline$D_{\text {ownership }}$ & Ownership & $0 / 1$ & $\begin{array}{l}\text { Domestic-owned individual firms (DIFs), } \\
\text { domestic-owned firms belonging to } \\
\text { Swedish corporate groups (DSCs), } \\
\text { domestic-owned multinational firms } \\
\text { (DMNEs) and foreign-owned multinational } \\
\text { firms (FMNEs). }\end{array}$ \\
\hline
\end{tabular}

Note: $\mathrm{c}$ denotes a continuous variable. The log physical capital $=\ln$ (physical capital +0.00001$)$. The firm employment growth rate has been winsorized with one percent of the observations to be modified in each tail. Values smaller than the $1^{\text {st }}$ percentile are replaced by the $1^{\text {st }}$ percentile, and a similar thing is done with the $99^{\text {th }}$ percentile. 
Table 2 Descriptive statistics

\begin{tabular}{|c|c|c|c|c|}
\hline Variables & Mean & Std. Dev. & Min & $\operatorname{Max}$ \\
\hline Employment & 11.305 & 124.913 & 1 & 23588 \\
\hline Employment growth & 0.027 & 0.305 & -0.916 & 1.099 \\
\hline Explorative innovation (5-year moving window) & 0.0012 & 0.0345 & 0 & 1 \\
\hline Exploitative innovation (5-year moving window) & 0.0018 & 0.0429 & 0 & 1 \\
\hline Explorative innovation (3-year moving window) & 0.0013 & 0.0361 & 0 & 1 \\
\hline Exploitative innovation (3-year moving window) & 0.0017 & 0.0418 & 0 & 1 \\
\hline Deflated wage (thousand SEK) & 202 & 142 & 0 & 33,100 \\
\hline Deflated physical capital (thousand SEK) & 7,778 & 218,000 & 0 & $72,800,000$ \\
\hline Deflated sector gross value added (thousand SEK) & $139,000,000$ & $119,000,000$ & 437 & $447,000,000$ \\
\hline \multicolumn{5}{|l|}{ Ownership: } \\
\hline DIFS & 0.806 & 0.395 & 0 & 1 \\
\hline DSCS & 0.139 & 0.346 & 0 & 1 \\
\hline DMNES & 0.026 & 0.160 & 0 & 1 \\
\hline FMNES & 0.028 & 0.165 & 0 & 1 \\
\hline \multicolumn{5}{|l|}{ Industry: } \\
\hline Agriculture, forestry and fishing & 0.089 & 0.284 & 0 & 1 \\
\hline Mining and quarrying & 0.017 & 0.128 & 0 & 1 \\
\hline Manufacturing & 0.105 & 0.307 & 0 & 1 \\
\hline Electricity, gas, steam and air conditioning supply & 0.002 & 0.043 & 0 & 1 \\
\hline $\begin{array}{l}\text { Water supply; sewerage, waste management and } \\
\text { remediation activities }\end{array}$ & 0.006 & 0.076 & 0 & 1 \\
\hline Construction & 0.131 & 0.337 & 0 & 1 \\
\hline $\begin{array}{l}\text { Wholesale and retail trade; repair of motor vehicles } \\
\text { and motorcycles }\end{array}$ & 0.205 & 0.404 & 0 & 1 \\
\hline Transportation and storage & 0.067 & 0.249 & 0 & 1 \\
\hline Accommodation and food service activities & 0.040 & 0.197 & 0 & 1 \\
\hline Information and communication & 0.046 & 0.209 & 0 & 1 \\
\hline Financial and insurance activities & 0.001 & 0.036 & 0 & 1 \\
\hline Real estate activities & 0.030 & 0.170 & 0 & 1 \\
\hline Professional, scientific and technical activities & 0.124 & 0.330 & 0 & 1 \\
\hline Administrative and support service activities & 0.028 & 0.164 & 0 & 1 \\
\hline $\begin{array}{l}\text { Public administration and defence; compulsory } \\
\text { social security }\end{array}$ & 0.000 & 0.001 & 0 & 1 \\
\hline Education & 0.022 & 0.147 & 0 & 1 \\
\hline Human health and social work activities & 0.034 & 0.181 & 0 & 1 \\
\hline Arts, entertainment and recreation & 0.017 & 0.128 & 0 & 1 \\
\hline $\begin{array}{l}\text { Activities of households as employers; } \\
\text { undifferentiated goods- and service-producing } \\
\text { activities of households for own use }\end{array}$ & 0.029 & 0.167 & 0 & 1 \\
\hline $\begin{array}{l}\text { Activities of extraterritorial organizations and } \\
\text { bodies }\end{array}$ & 0.009 & 0.096 & 0 & 1 \\
\hline Observations & $2,159,666$ & & & \\
\hline
\end{tabular}


Table 3 Pairwise correlation coefficients

\begin{tabular}{|c|c|c|c|c|c|c|c|c|c|}
\hline & $(1)$ & $(2)$ & (3) & (4) & $(5)$ & $(6)$ & $(7)$ & $(8)$ & (9) \\
\hline (1) Employment & 1 & & & & & & & & \\
\hline (2) Employment growth & 0.0011 & 1 & & & & & & & \\
\hline (3) Explorative innovation (5-year moving window) & 0.0966 & 0.0008 & 1 & & & & & & \\
\hline (4) Exploitative innovation (5-year moving window) & 0.124 & 0.0005 & 0.4601 & 1 & & & & & \\
\hline (5) Explorative innovation (3-year moving window) & 0.1048 & 0.0006 & 0.9572 & 0.5108 & 1 & & & & \\
\hline (6) Exploitative innovation (3-year moving window) & 0.1201 & 0.0005 & 0.4469 & 0.9742 & 0.4622 & 1 & & & \\
\hline (5) Deflated wage & 0.0413 & -0.0701 & 0.0352 & 0.0498 & 0.0375 & 0.0486 & 1 & & \\
\hline (6) Deflated physical capital & 0.2421 & -0.002 & 0.0489 & 0.0693 & 0.0551 & 0.0653 & 0.0355 & 1 & \\
\hline (7) Deflated sector gross value added & 0.044 & -0.0202 & 0.0419 & 0.0532 & 0.0442 & 0.0517 & 0.1026 & 0 & 1 \\
\hline
\end{tabular}


Table 4 Descriptive statistics by ownership type

\begin{tabular}{|l|l|l|l|l|l|l|l|l|}
\hline & \multicolumn{2}{|l|}{} & DIFs & \multicolumn{2}{l|}{ DMNEs } & \multicolumn{2}{l|}{ FMNEs } \\
\hline Variables & Mean & Std. Dev. & Mean & Std. Dev. & Mean & Std. Dev. & Mean & Std. Dev. \\
\hline Employment & 4.237 & 45.721 & 19.253 & 125.738 & 96.531 & 477.422 & 95.124 & 433.745 \\
\hline Employment growth & 0.031 & 0.313 & 0.008 & 0.273 & 0.008 & 0.241 & 0.004 & 0.247 \\
\hline Explorative innovation (5-year moving window) & 0.00036 & 0.01888 & 0.00144 & 0.03788 & 0.01610 & 0.12584 & 0.01002 & 0.09959 \\
\hline Exploitative innovation (5-year moving window) & 0.00038 & 0.01937 & 0.00200 & 0.04463 & 0.02783 & 0.16447 & 0.01880 & 0.13580 \\
\hline Explorative innovation (3-year moving window) & 0.00037 & 0.01930 & 0.00153 & 0.03909 & 0.01792 & 0.13266 & 0.01126 & 0.10552 \\
\hline Exploitative innovation (3-year moving window) & 0.00036 & 0.01886 & 0.00189 & 0.04343 & 0.02639 & 0.16029 & 0.01790 & 0.13259 \\
\hline Deflated wage (thousand SEK) & 181 & 127 & 266 & 130 & 349 & 230 & 371 \\
\hline Deflated physical capital (thousand SEK) & 1,346 & 41,200 & 21,900 & 385,000 & 79,100 & 768,000 & 55,800 & 583,000 \\
\hline Deflated sector gross value added (thousand SEK) & $129,000,000$ & $114,000,000$ & $166,000,000$ & $127,000,000$ & $217,000,000$ & $142,000,000$ & $209,000,000$ & $129,000,000$ \\
\hline Observations & $1,741,671$ & & 300,574 & & 57,035 & & 60,386 \\
\hline
\end{tabular}


Table 5 OLS regression result (5-year moving window)

\begin{tabular}{|c|c|c|c|}
\hline & (1) & (2) & (3) \\
\hline L. $\Delta$ log employment & $-0.259 * * *$ & $-0.259 * * *$ & $-0.259 * * *$ \\
\hline L2. $\Delta$ log employment & $\begin{array}{l}(-274.25) \\
-0.0749 * * * \\
(-83.62)\end{array}$ & $\begin{array}{l}(-274.24) \\
-0.0749 * * * \\
(-83.61)\end{array}$ & $\begin{array}{l}(-274.25) \\
-0.0749 * * * \\
(-83.62)\end{array}$ \\
\hline Exploitative innovation & & $\begin{array}{l}0.0222 * * * * \\
(3.00)\end{array}$ & $\begin{array}{l}0.0126 \\
(1.55)\end{array}$ \\
\hline L. Exploitative innovation & & $\begin{array}{l}0.0153 * * \\
(2.07)\end{array}$ & $\begin{array}{l}0.00866 \\
(1.10)\end{array}$ \\
\hline L2. Exploitative innovation & & $\begin{array}{l}-0.0113^{*} \\
(-1.70)\end{array}$ & $\begin{array}{l}-0.0142 * * \\
(-2.07)\end{array}$ \\
\hline Explorative innovation & $\begin{array}{l}0.0208 * * * \\
(2.78)\end{array}$ & & $\begin{array}{l}0.0167 * * \\
(2.06)\end{array}$ \\
\hline L. Explorative innovation & $\begin{array}{l}0.0168^{* *} \\
(2.40)\end{array}$ & & $\begin{array}{l}0.0117 \\
(1.53)\end{array}$ \\
\hline L2. Explorative innovation & $\begin{array}{l}0.0133 * * \\
(2.07)\end{array}$ & & $\begin{array}{l}0.0135^{*} \\
(1.87)\end{array}$ \\
\hline$\Delta$. Log wage & $\begin{array}{l}-0.0161 * * * \\
(-27.87)\end{array}$ & $\begin{array}{l}-0.0161 * * * \\
(-27.87)\end{array}$ & $\begin{array}{l}-0.0161 * * * \\
(-27.87)\end{array}$ \\
\hline$\Delta$. Log physical capital & $\begin{array}{l}0.00381 \text { *** } \\
(59.79)\end{array}$ & $\begin{array}{l}0.00381 \text { *** } \\
(59.80)\end{array}$ & $\begin{array}{l}0.00381 \text { *** } \\
(59.79)\end{array}$ \\
\hline$\Delta$. Log sector gross value added & $\begin{array}{l}0.00606 * * * \\
(4.94)\end{array}$ & $\begin{array}{l}0.00606 * * * \\
(4.94)\end{array}$ & $\begin{array}{l}0.00606 * * * \\
(4.94)\end{array}$ \\
\hline \multicolumn{4}{|l|}{ Ownership (base is DIFs) } \\
\hline DSCs & $\begin{array}{l}-0.000471 \\
(-0.67)\end{array}$ & $\begin{array}{l}-0.000454 \\
(-0.64)\end{array}$ & $\begin{array}{l}-0.000468 \\
(-0.66)\end{array}$ \\
\hline DMNEs & $\begin{array}{l}0.00398 * * * \\
(2.66)\end{array}$ & $\begin{array}{l}0.00417 * * * \\
(2.78)\end{array}$ & $\begin{array}{l}0.00399 * * * \\
(2.66)\end{array}$ \\
\hline FMNEs & $\begin{array}{l}-0.00638^{* * * *} \\
(-4.39)\end{array}$ & $\begin{array}{l}-0.00630 \text { *** } \\
(-4.32)\end{array}$ & $\begin{array}{l}-0.00637 \text { *** } \\
(-4.38)\end{array}$ \\
\hline Year dummy & Yes & Yes & Yes \\
\hline $\begin{array}{l}\text { Region dummy } \\
\text { Industry dummy } \\
\text { Constant }\end{array}$ & $\begin{array}{l}\text { Yes } \\
\text { Yes } \\
-0.0275^{* * *} \\
(-6.30)\end{array}$ & $\begin{array}{l}\text { Yes } \\
\text { Yes } \\
-0.0275^{* * *} \\
(-6.30)\end{array}$ & $\begin{array}{l}\text { Yes } \\
\text { Yes } \\
-0.0275^{* * *} \\
(-6.30)\end{array}$ \\
\hline Observations & $1,173,311$ & $1,173,311$ & $1,173,311$ \\
\hline
\end{tabular}

Note: $* * *$ denotes $0.1 \%$ significance; $* *$ denotes $1 \%$ significance; $*$ denotes $5 \%$ significance. 
Table 6 GMM regression result (5-year moving window)

\begin{tabular}{|c|c|c|c|}
\hline & (1) & (2) & (3) \\
\hline L. $\Delta$ log employment & 0.103 & 0.126 & 0.0963 \\
\hline L2. $\Delta$ log employment & $\begin{array}{l}(0.98) \\
0.0212 \\
(1.49)\end{array}$ & $\begin{array}{l}(0.90) \\
0.0162 \\
(0.93)\end{array}$ & $\begin{array}{l}(0.90) \\
0.0220 \\
(1.53)\end{array}$ \\
\hline Exploitative innovation & & $\begin{array}{l}0.0232 * \\
(1.92)\end{array}$ & $\begin{array}{l}0.00309 \\
(0.24)\end{array}$ \\
\hline L. Exploitative innovation & & $\begin{array}{l}0.0170 * \\
(1.75)\end{array}$ & $\begin{array}{l}0.00405 \\
(0.38)\end{array}$ \\
\hline L2. Exploitative innovation & & $\begin{array}{l}-0.00135 \\
(-0.15)\end{array}$ & $\begin{array}{l}-0.00597 \\
(-0.65)\end{array}$ \\
\hline Explorative innovation & $\begin{array}{l}0.0347 * * * \\
(3.19)\end{array}$ & & $\begin{array}{l}0.0336 * * * \\
(2.86)\end{array}$ \\
\hline L. Explorative innovation & $\begin{array}{l}0.0262 * * * \\
(2.77)\end{array}$ & & $\begin{array}{l}0.0245^{* *} \\
(2.25)\end{array}$ \\
\hline L2. Explorative innovation & $\begin{array}{l}0.0218 * * \\
(2.49)\end{array}$ & & $\begin{array}{l}0.0220 * * \\
(2.19)\end{array}$ \\
\hline$\Delta$. Log wage & $\begin{array}{l}-0.0540 * * * \\
(-11.92)\end{array}$ & $\begin{array}{l}-0.0275^{* * *} \\
(-6.93)\end{array}$ & $\begin{array}{l}-0.0537 * * * \\
(-11.64)\end{array}$ \\
\hline$\Delta$. Log physical capital & $\begin{array}{l}0.00213 * * * \\
(22.50)\end{array}$ & $\begin{array}{l}0.00327 * * * \\
(18.77)\end{array}$ & $\begin{array}{l}0.00213 * * * \\
(22.52)\end{array}$ \\
\hline$\Delta$. Log sector gross value added & $\begin{array}{l}0.00304 * \\
(1.88)\end{array}$ & $\begin{array}{l}0.00464 * * * \\
(3.06)\end{array}$ & $\begin{array}{l}0.00306^{*} \\
(1.90)\end{array}$ \\
\hline $\begin{array}{l}\text { Ownership (base is DIFs) } \\
\text { DSCs }\end{array}$ & $\begin{array}{l}0.000981 \\
(1.10)\end{array}$ & $\begin{array}{l}0.000656 \\
(0.79)\end{array}$ & $\begin{array}{l}0.000983 \\
(1.11)\end{array}$ \\
\hline DMNEs & $\begin{array}{l}0.00200 \\
(1.04)\end{array}$ & $\begin{array}{l}0.00203 \\
(1.08)\end{array}$ & $\begin{array}{l}0.00206 \\
(1.06)\end{array}$ \\
\hline FMNEs & $\begin{array}{l}-0.00424 * * \\
(-2.31)\end{array}$ & $\begin{array}{l}-0.00465 * * * \\
(-2.59)\end{array}$ & $\begin{array}{l}-0.00424 * * \\
(-2.29)\end{array}$ \\
\hline Year dummy & Yes & Yes & Yes \\
\hline $\begin{array}{l}\text { Region dummy } \\
\text { Industry dummy } \\
\text { Constant }\end{array}$ & $\begin{array}{l}\text { Yes } \\
\text { Yes } \\
-0.0514 * * * \\
(-9.58)\end{array}$ & $\begin{array}{l}\text { Yes } \\
\text { Yes } \\
-0.0354 * * * \\
(-6.84)\end{array}$ & $\begin{array}{l}\text { Yes } \\
\text { Yes } \\
-0.0515^{* * * *} \\
(-9.63)\end{array}$ \\
\hline Observations & $1,173,311$ & $1,173,311$ & $1,173,311$ \\
\hline Sargan value & 83.88 & 52.17 & 84.5 \\
\hline Sargan p-value & 0.998 & 0.833 & 0.996 \\
\hline $\operatorname{AR}(1)$ & -5.72 & -4.42 & -5.57 \\
\hline AR (1) p-value & 0.000 & 0.000 & 0.000 \\
\hline $\operatorname{AR}(2)$ & 1.52 & 1.33 & 1.43 \\
\hline AR (2) p-value & 0.129 & 0.183 & 0.154 \\
\hline
\end{tabular}

Note: $* * *$ denotes $0.1 \%$ significance; $* *$ denotes $1 \%$ significance; $*$ denotes $5 \%$ significance. 
Figure 1 Exploration/exploitation innovation and average firm growth rate

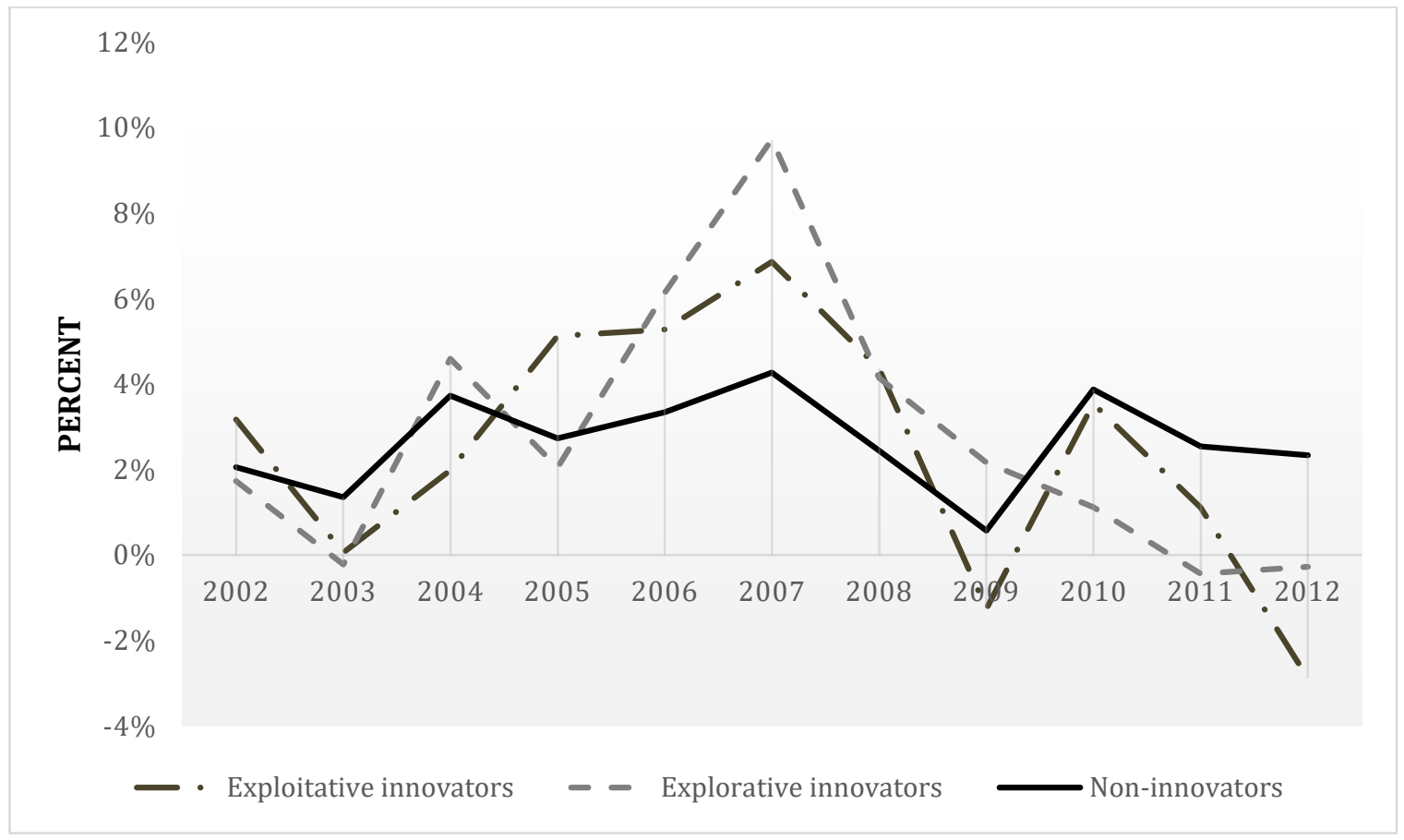


Appendix A OLS regression result (3-year moving window)

\begin{tabular}{|c|c|c|c|}
\hline & (1) & (2) & (3) \\
\hline L. $\Delta$ log employment & $-0.257 * * *$ & $-0.257 * * *$ & $-0.257 * * *$ \\
\hline L2. $\Delta$ log employment & $\begin{array}{l}(-277.15) \\
-0.0737 * * * \\
(-83.22)\end{array}$ & $\begin{array}{l}(-277.14) \\
-0.0737 * * * \\
(-83.22)\end{array}$ & $\begin{array}{l}(-277.15) \\
-0.0737 * * * \\
(-83.22)\end{array}$ \\
\hline Exploitative innovation & & $\begin{array}{l}0.0208 * * * \\
(2.87)\end{array}$ & $\begin{array}{l}0.0121 \\
(1.51)\end{array}$ \\
\hline L. Exploitative innovation & & $\begin{array}{l}0.0132 * \\
(1.83)\end{array}$ & $\begin{array}{l}0.00831 \\
(1.08)\end{array}$ \\
\hline L2. Exploitative innovation & & $\begin{array}{l}-0.00929 \\
(-1.42)\end{array}$ & $\begin{array}{l}-0.0107 \\
(-1.60)\end{array}$ \\
\hline Explorative innovation & $\begin{array}{l}0.0177 * * * \\
(2.60)\end{array}$ & & $\begin{array}{l}0.0137^{*} \\
(1.87)\end{array}$ \\
\hline L. Explorative innovation & $\begin{array}{l}0.0145 * * \\
(2.29)\end{array}$ & & $\begin{array}{l}0.00925 \\
(1.31)\end{array}$ \\
\hline L2. Explorative innovation & $\begin{array}{l}0.00881 \\
(1.50)\end{array}$ & & $\begin{array}{l}0.00713 \\
(1.07)\end{array}$ \\
\hline$\Delta$. Log wage & $\begin{array}{l}-0.0178 \text { *** } \\
(-32.56)\end{array}$ & $\begin{array}{l}-0.0178 \text { *** } \\
(-32.56)\end{array}$ & $\begin{array}{l}-0.0178 \text { *** } \\
(-32.56)\end{array}$ \\
\hline$\Delta$. Log physical capital & $\begin{array}{l}0.00331 * * * \\
(54.81)\end{array}$ & $\begin{array}{l}0.00331 * * * \\
(54.81)\end{array}$ & $\begin{array}{l}0.00331 * * * \\
(54.81)\end{array}$ \\
\hline$\Delta$. Log sector gross value added & $\begin{array}{l}0.00498 * * * \\
(4.28)\end{array}$ & $\begin{array}{l}0.00497 * * * \\
(4.27)\end{array}$ & $\begin{array}{l}0.00498 * * * \\
(4.28)\end{array}$ \\
\hline \multicolumn{4}{|l|}{ Ownership (base is DIFs) } \\
\hline DSCs & $\begin{array}{l}-0.000187 \\
(-0.28)\end{array}$ & $\begin{array}{l}-0.000173 \\
(-0.26)\end{array}$ & $\begin{array}{l}-0.000185 \\
(-0.28)\end{array}$ \\
\hline DMNEs & $\begin{array}{l}0.00487 * * * \\
(3.43)\end{array}$ & $\begin{array}{l}0.00502 * * * \\
(3.53)\end{array}$ & $\begin{array}{l}0.00485^{* * *} \\
(3.41)\end{array}$ \\
\hline FMNEs & $\begin{array}{l}-0.00589 * * * \\
(-4.27)\end{array}$ & $\begin{array}{l}-0.00582 * * * \\
(-4.22)\end{array}$ & $\begin{array}{l}-0.00590 * * * \\
(-4.28)\end{array}$ \\
\hline Year dummy & Yes & Yes & Yes \\
\hline $\begin{array}{l}\text { Region dummy } \\
\text { Industry dummy } \\
\text { Constant }\end{array}$ & $\begin{array}{l}\text { Yes } \\
\text { Yes } \\
-0.0175 * * * \\
(-4.23)\end{array}$ & $\begin{array}{l}\text { Yes } \\
\text { Yes } \\
-0.0175^{* * *} \\
(-4.23)\end{array}$ & $\begin{array}{l}\text { Yes } \\
\text { Yes } \\
-0.0175^{* * *} \\
(-4.23)\end{array}$ \\
\hline Observations & $1,173,311$ & $1,173,311$ & $1,173,311$ \\
\hline
\end{tabular}

Note: $* * *$ denotes $0.1 \%$ significance; $* *$ denotes $1 \%$ significance; $*$ denotes $5 \%$ significance. 
Appendix B GMM regression result (3-year moving window)

\begin{tabular}{|c|c|c|c|}
\hline & (1) & $(2)$ & (3) \\
\hline L. $\Delta$ log employment & 0.128 & 0.0787 & 0.0968 \\
\hline L2. $\Delta$ log employment & $\begin{array}{l}(0.61) \\
0.0152 \\
(0.61)\end{array}$ & $\begin{array}{l}(0.59) \\
0.0200 \\
(1.18)\end{array}$ & $\begin{array}{l}(0.92) \\
0.0202 \\
(1.41)\end{array}$ \\
\hline Exploitative innovation & & $\begin{array}{l}0.0249 * * \\
(2.18)\end{array}$ & $\begin{array}{l}0.00663 \\
(0.52)\end{array}$ \\
\hline L. Exploitative innovation & & $\begin{array}{l}0.0160 * \\
(1.70)\end{array}$ & $\begin{array}{l}0.00552 \\
(0.52)\end{array}$ \\
\hline L2. Exploitative innovation & & $\begin{array}{l}-0.00141 \\
(-0.16)\end{array}$ & $\begin{array}{l}-0.00386 \\
(-0.43)\end{array}$ \\
\hline Explorative innovation & $\begin{array}{l}0.0299 * * \\
(2.17)\end{array}$ & & $\begin{array}{l}0.0258 * * \\
(2.38)\end{array}$ \\
\hline L. Explorative innovation & $\begin{array}{l}0.0240 * * \\
(2.15)\end{array}$ & & $\begin{array}{l}0.0191^{*} \\
(1.87)\end{array}$ \\
\hline L2. Explorative innovation & $\begin{array}{l}0.0185^{*} \\
(1.90)\end{array}$ & & $\begin{array}{l}0.0151 \\
(1.60)\end{array}$ \\
\hline$\Delta$. Log wage & $\begin{array}{l}-0.0289 * * * \\
(-5.07)\end{array}$ & $\begin{array}{l}-0.0276 * * * \\
(-7.60)\end{array}$ & $\begin{array}{l}-0.0540 * * * \\
(-12.18)\end{array}$ \\
\hline$\Delta$. Log physical capital & $\begin{array}{l}0.00279 * * * \\
(11.76)\end{array}$ & $\begin{array}{l}0.00285 * * * \\
(17.90)\end{array}$ & $\begin{array}{l}0.00180 * * * \\
(19.83)\end{array}$ \\
\hline$\Delta$. Log sector gross value added & $\begin{array}{l}0.00357 * * \\
(2.29)\end{array}$ & $\begin{array}{l}0.00373 * * * \\
(2.63)\end{array}$ & $\begin{array}{l}0.00224 \\
(1.45)\end{array}$ \\
\hline \multicolumn{4}{|l|}{ Ownership (base is DIFs) } \\
\hline DSCs & $\begin{array}{l}0.000912 \\
(1.14)\end{array}$ & $\begin{array}{l}0.000942 \\
(1.21)\end{array}$ & $\begin{array}{l}0.00112 \\
(1.31)\end{array}$ \\
\hline DMNEs & 0.00270 & $0.00324 *$ & $0.00319 *$ \\
\hline & $(1.40)$ & $(1.84)$ & $(1.70)$ \\
\hline FMNEs & $\begin{array}{l}-0.00409 * * \\
(-2.26)\end{array}$ & $\begin{array}{l}-0.00407 * * \\
(-2.41)\end{array}$ & $\begin{array}{l}-0.00356^{* *} \\
(-1.99)\end{array}$ \\
\hline Year dummy & Yes & Yes & Yes \\
\hline Region dummy & Yes & Yes & Yes \\
\hline Industry dummy & Yes & Yes & Yes \\
\hline Constant & $\begin{array}{l}-0.0258 * * * \\
(-5.17)\end{array}$ & $\begin{array}{l}-0.0259 * * * \\
(-5.39)\end{array}$ & $\begin{array}{l}-0.0363 * * * \\
(-7.09)\end{array}$ \\
\hline Observations & $1,173,311$ & $1,173,311$ & $1,173,311$ \\
\hline Sargan value & 15.06 & 54.42 & 81.32 \\
\hline Sargan p-value & 0.303 & 0.771 & 0.998 \\
\hline $\mathrm{AR}(1)$ & -2.95 & -4.42 & -5.65 \\
\hline AR (1) p-value & 0.003 & 0.000 & 0.000 \\
\hline $\operatorname{AR}(2)$ & 0.90 & 1.08 & 1.47 \\
\hline AR (2) p-value & 0.368 & 0.280 & 0.141 \\
\hline
\end{tabular}

Note: $* * *$ denotes $0.1 \%$ significance; $* *$ denotes $1 \%$ significance; $*$ denotes $5 \%$ significance 